\title{
PANAMA PAPERS DAN DISKURSUS TENTANG PERLINDUNGAN DATA DI INDONESIA: SUATU PERSPEKTIF TEORI KEADILAN BERMARTABAT
}

\author{
Jeferson Kameo \\ Mahasiswa Program Doktor Ilmu Hukum \\ Universitas 17 Agustus 1945 Surabaya \\ Korespondensi: yagkameo@yahoo.com
}

\begin{abstract}
Abstrak
"Setiap orang berhak atas perlindungan diri pribadi, keluarga, kehormatan, martabat, dan harta benda yang di bawah kekuasaannya, serta berhak atas rasa aman dan perlindungan dari ancaman ketakutan untuk berbuat atau tidak berbuat sesuatu yang merupakan hak asasi”. Inilah rumusan dari Pasal 28 G Ayat (1) dari Undang-Undang Dasar, yang dinyatakan Perubahannya yang Kedua dalam suatu Ketetapan Majelis Permusyawaratan Rakyat Republik Indonesia. Dalam rumusan ketentuan ini orang dapat menyuling semua asas yang mengatur perlindungan data dalam Sistem Hukum Pancasila. Di samping rumusan ketentuan di atas, sejumlah rumusan kaedah hukum lainnya berisi asas-asas yang sama dapat juga ditemukan dalam beberapa Undang-Undang yang berlaku dalam sistem hukum Indonesia. Antara lain, UU No. 8 tahun 2011 tentang ITE. Penulis artikel ini berpendapat bahwa seluruh rumusan ketentuan dimaksud adalah bentuk-bentuk perwujudan diri dari jiwa bangsa (Volksgeist) tempat orang dapat menemukan asas-asas dan kaidah yang mengatur perlindungan data dalam Sistem Hukum Pancasila. Satu dari asas hukum yang melindungi data pribadi dapat digunakan untuk memecahkan skandal terkini, yaitu Panamapapers.
\end{abstract}

Kata-kata Kunci: Panamapapers; Perlindungan Data; Data Pribadi.

\begin{abstract}
"Every person has the rights to get protection on his personal/privacy, family, honor, dignity and properties under his power, and has rights to feel secure and to get protection from fear of any threat in order to do or not to do something related to their fundamental rights". This is the formulation of the Article 28 G (1) of the Indonesian Basic Act, mentioned in its Second Amendment mentioned in the Decision of the People's Consultative Assembly of the Republic of Indonesia. In this stipulation one could distil all the legal principles governing data protection in the Pancasila Legal System. Apart from the stipulation mentioned above, some further formulation of legal rules contained similar principles may also be found in several Acts in the Indonesian legal system. Among those Acts, is the Act number 8 of 2011 concerning Information and Electronic Transaction. This writer argues that all of the stipulations are forms of manifestation of the spirit of the Indonesian people (Volksgeist) in which one could find rules and principles governing data protection in the Pancasila Legal System. One of the principles of Law that protect the personal data could be used in order to solve the rescent scandal called Panamapapers.
\end{abstract}

Key Words: Panamapapers; Data Protection; Personal Data. 


\section{PENDAHULUAN}

Memulai pembahasannya mengenai perlindungan data pribadi dalam suatu Seminar Internasional bertema: Personal Data Protection yang diselenggarakan Fakultas Hukum Universitas 17 Agustus 1945 Surabaya pada tanggal 31 Maret 2016, Prof. Dr. Ida Bagus Rahmadi Supancana mengemukakan suatu gagasan hukum yang cukup aktual, penting dan menarik. Gagasan hasil dikte hukum (the dictate of the Law) dimaksud, yaitu gagasan mengenai perlindungan data, dan data pribadi.

Gagasan hukum kontemporer, atau gagasan yang datang dari hukum sebagai sumber hukum tersebut relevan dan aktual menjadi suatu diskursus dalam tulisan ini. Terutama, karena di Indonesia dan dunia belakangan ini publik konvensional dan netizen baru saja diguncang oleh mega skandal dunia, yaitu bocornya data, dan data pribadi di dunia maya Panama Papers. Perlu dikemukakan bahwa mega skandal Panama Papers adalah bocornya sejumlah data, dan data pribadi berbentuk informasi elektronik atau data elektronik/digital.

Data tersebut berisi informasi mengenai sejumlah orang pribadi. Yang menghebohkan dalam laporan Panama Papers yang bocor atau memang dibocorkan tersebut, tersebut pribadipribadi dalam dokumen elektronik dimaksud telah menanamkan atau menginvestasikan uang mereka di suatu Republik Surga Pajak, suatu negara pulau yang terletak di tengah Samudera
India, berlokasi di Timur Afrika. Surga pajak artinya di dalam jurisdiksi bernama "surga" tersebut, para penanam modal yang menanamkan modalnya, begitu pula jika ada hasil yang timbul karena investasi dimaksud, tidak dikenakan pajak.

Data itu menghebohkan karena di saat-saat Indonesia sedang butuh dana untuk digunakan melalui investasi di dalam negeri para petinggi itu justru "melarikan" dana ke luar negeri. Motifnya, konon supaya tidak membayar pajak di dalam negeri. Padahal orang yang tidak mau membayar pajak itu melanggar hukum Sorgawi dan Hukum Positif di Sorga maupun di Dunia. Data itu, kalau benar, telah menyebabkan dua kerugian sekaligus. Devisa milik orang Indonesia yang diperoleh di Indonesia justru dilarikan dan mencari "jodoh" ke luar negeri. "Di mana nasionalisme para petinggi negara itu?", begitulah pertanyaan para pemerhati nasionalisme. Kerugian selanjutnya, kalau ada transaksi yang menggunakan dana dari para petinggi di atas yang ditanamkan di luar negeri, maka pasti ada pajak yang dapat dipungut untuk membiayai kebutuhan negara.

Dikabarkan secara meluas, baik itu melalui media konvensional seperti koran cetak, televisi, maupun internet bahwa ada pemimpin dunia yang mundur dari jabatannya, hanya garagara skandal data dalam laporan Panama Papers itu. Mereka mundur karena mereka merasa berdosa terhadap publik dan tanah airnya sendiri. Begitu pula, dalam Panama Papers itu terdapat 
sejumlah nama-nama petinggi negara Indonesia, seperti: Rini Soewarno, Ketua BPK, Harry Azhar Aziz, dan Menteri Koordinator Bidang Hukum dan Keamanan Luhut B. Panjaitan. Hanya saja, kalau di luar negeri para petinggi mundur karena gosip seperti itu, di Indonesia, menanggapi pemberitaan tentang informasi mengenai diri mereka, menteri Rini dan Luhut, dua petinggi negara dalam Kabinet Kerja Presiden Joko Widodo membantah kebenaran data mengenai diri mereka di Panama Papers tersebut.

Menurut Luhut Panjaitan, data mengenai dirinya tersebut tidak benar. Dia mencontohkan, bahwa alamat rumahnya yang tertera dalam Panama Papers adalah salah. Luhut tidak pernah bertempat tinggal di alamat yang disebutkan dalam Panama Papers itu. Oleh sebab itu, pemberitaan yang meluas mengenai kaitan antara aktivitas penanaman modal atau investasi di negara pulau surga pajak dari namanama para petinggi Republik Indonesia tersebut dalam Panama Papers telah dirasakan menyebabkan kerugian di pihak pribadi-pribadi yang data diri mereka terdapat dalam Panama Papers dimaksud.

Data diri yang konon keliru dalam Panama Papers itu berpotensi "digunakan" publik untuk memberikan judgement, terhadap pribadi-pribadi petinggi negara dimaksud di atas. Sejumlah kalangan bahkan berpeluang mengutilisasi data pribadi yang konon keliru dalam Panama Papers itu sebagai "amunisi" untuk menyerang lawan politik. Bukan tidak mungkin, kalau ada petualang politik yang sudah lama mengincar kursi menteri BUMN yang basah itu, dan juga kursi Menteri yang memiliki kekuasaan besar yaitu Koordinator Politik, Hukum dan Keamanan serta Ketua lembaga auditor Negara yang legitimasinya adalah dalam undang-undang dasar, yaitu BPK misalnya, mereka dapat menggunakan data pribadi dalam Panama Papers itu sebagai "kunci" untuk membuka pintu dukungan politik dari masa. Boleh jadi data yang mungkin saja benar tetapi mungkin saja keliru itu dapat menjadi "alasan yang kuat", justification, bagi para petualang politik tersebut untuk memenangkan pikiran dan hati Joko Widodo "mengosongkan kursi" (reshuffle) bagi para petualang politik tersebut. Atau, setidak-tidaknya dalam jadwal "pengosongan dan atau perombakan” (reshuffle kabinet Jilid II) tersingkirlah Rini dan Luhut. Sebab, mungkin saja oleh para petualang politik itu, Rini dan Luhut adalah "penghalang terberat" bagi agenda politik para petualang politik dimaksud.

Cerita yang menimpa para petinggi Republik Indonesia sebagaimana diberitakan secara meluas tersebut mirip dengan pandangan yang pernah dikemukakan oleh David Bainbridge. Lima belas tahun yang lalu saja, menurut Bainbridge, "There are many horror stories about people who had information wrongly attributed to them and stored on computer". (Artinya, ada banyak cerita horor mengenai orang yang menemukan bahwa ada informasi yang salah mengenai diri mereka dan 
tersimpan dalam komputer; baik komputer yang tidak dihubungkan dengan jaringan telekomunikasi, maupun komputer yang terhubung dengan jaringan telekomunikasi atau internet).

Bainbridge mengutip suatu cerita nyata sederhana, dan dapat menjadi perumpamaan serta disebut Bainbridge dalam kutipan di atas sebagai jenis cerita horor. Cerita mengenai seorang pria yang menderita kerugian karena data dirinya yang salah, telah dikumpul, diolah dan dikuasai serta digunakan pihak ketiga, dalam hal ini yaitu pihak kepolisian, untuk melakukan penilaian (judgement) yang merugikan tentang dirinya, dan bahkan penilaian yang kurang lebih berpengaruh bagi masa depannya. Mengutip suatu Majalah Internasional yang sangat terkenal, The Times, Bainbridge bercerita tentang nasib pria dimaksud.

Menurut Bainbridge pria itu adalah seorang yang berkelakuan baik. Pria itu belum pernah dinyatakan bersalah oleh pihak pengadilan karena melakukan pelanggaran hukum apa pun. Namun, pria itu telah ditangkap oleh pihak kepolisian di negara Komunis. Alasan penangkapan oleh pihak kepolisian Komunis itu, adalah karena menurut personal data yang dihimpun dan dikelola serta disimpan pihak kepolisian, pria tersebut pernah ketahuan telah menyetir pada saat yang bersamaan sejatinya dia telah dinyatakan didiskualifikasi untuk mengemudikan kendaraan. Alasan penangkapan oleh pihak kepolisian Komunis terhadap pria itu didasarkan kepada informasi mengenai pria yang bersangkutan dimaksud. Adapun informasi tersebut, menurut Majalah Time, adalah suatu informasi elektronik yang berada di komputer milik pihak kepolisian Komunis. Namun, menurut laporan majalah Time, data itu ternyata tidak benar. Data mengenai pria yang berkelakuan baik dan saleh yang dipergunakan dan diutilisasi pihak kepolisian Komunis sebagai dasar untuk menangkap pria dimaksud adalah data milik orang lain yang memiliki persamaan nama dengan pria berkelakuan baik dan saleh dan telah ditangkap polisi itu.

Dengan perkataan lain, sejumlah keterangan yang mendetail dan yang telah menyebabkan pria dimaksud di atas didiskualifikasi untuk mengemudikan kendaraan bermotor telah ditempatkan oleh pihak kepolisian di komputer di kantor polisi. Padahal, data yang dimasukkan pihak kepolisian terhadap nama dari pria tersebut adalah data yang salah. Salah dalam pengertian, data yang ada di komputer polisi bukan data milik pria yang ditangkap. Hanya nama dari pria yang sebenarnya "jahat", dan pria berkelakuan baik dan saleh tetapi ditangkap pihak kepolisian itu ternyata memiliki kesamaan. Menurut Bainbridge, sebagai akibat dari penangkapan oleh pihak polisi, pria tidak berdosa itu kehilangan pekerjaannya. Bukan hanya itu, mobil milik pria tersebut juga ikut disita. 
Melanjutkan kutipannya dari majalah Time, Bainbridge bercerita bahwa belakangan pria innocence tersebut membutuhkan waktu kurang lebih empat bulan. Bukan hanya waktu yang relatif lama, tetapi juga tenaga dan biaya serta nama baik yang sudah terlanjur jadi buruk menemani pria "salah tangkap" itu, untuk melacak sendiri siapa pria lain yang sebenarnya dimaksudkan oleh pihak kepolisian yang menangkapnya itu. Dimaksudkan dengan pria yang sebenarnya, yaitu pria pemilik data yang oleh kepolisian telah dikumpulkan, diolah dan dipergunakan untuk melakukan penilaian dan berakhir dengan penangkapan terhadap pria yang tidak bersalah tersebut. Dengan perkataan lain, kerugian besar telah menimpa pria di yang ditangkap pihak kepolisian di atas. Dia kehilangan waktu, pekerjaan, mobil dan hidup dengan tekanan psikologis yang tidak baik; sekalipun pada akhirnya pria yang ditangkap secara salah oleh pihak kepolisian itu, belakangan dipulihkan nama baiknya.

Kembali kepada gunjang-ganjing di Republik seperti dikemukakan di atas, kalau memang benar bahwa data dari para petinggi Republik Indonesia dalam Panama Papers itu, maka publikasi Panama Papers adalah suatu model jurnalisme investigatif yang profesional. Hanya saja, kalau data di dalam Panama Papers itu adalah data yang tidak benar, atau data pribadi yang sama dengan data dalam cerita Bainbridge sebagaimana dikemukakan di atas, maka pemberitaan mengenai Panama Papers telah mengakibatkan kerugian besar kepada pihak-pihak yang namanya terdapat di dalam Panama Papers dimaksud di atas.

Hukum, seharusnya berperan, tidak saja untuk mencegah terjadinya pengumpulan, pengolahan, penyimpanan dan penggunaan data pribadi yang merugikan orang lain sebagaimana dicontohkan Bainbridge di atas, tetapi juga eksis untuk memulihkan kembali kerugian yang timbul pada pihak-pihak seperti karena pemberitaan mengenai Panamapapers yang mungkin saja tidak benar. Apakah ada hukum seperti itu di dalam sistem hukum Pancasila? Soal ini dibicarakan dalam artikel ini.

\section{PEMBAHASAN}

\section{Perlindungan Data di Indonesia}

Tesis dalam artikel ini, yaitu bahwa di dalam sistem hukum Indonesia yang berdasarkan Pancasila, juga ada hukum yang memberikan perlindungan kepada pihak yang dirugikan, seperti yang dialami oleh pria dalam cerita Bainbridge atau mungkin saja seperti yang dialami oleh para petinggi negeri ini, seperti sudah pula dikemukakan di atas.

Menopang tesis tersebut, perkenankan saya meminjam pandangan Prof. Supancana, yang nampaknya mengandung kaidah bahwa hukum yang mengatur mengenai perlindungan data di Indonesia sejatinya dapat ditemukan dalam satu dari begitu banyak sumbernya di Indonesia, yaitu dalam Pasal 28 G (1) Undang-Undang Dasar 1945 (UUD 45). Pandangan Prof. Supancana itu sepertinya hendak 
menegaskan kembali, bahwa hukum positif, atau Volkgeist Indonesia sejatinya juga sudah mengatur tentang perlindungan data. Penopang lain atas tesis untuk artikel saya ini, saya berpendapat bahwa pandangan Prof. Supancana tersebut sejalan dengan suatu perspektif dalam Teori Keadilan Bermartabat. Menurut perspekitf Teori Keadilan Bermartbat, yaitu suatu teori atau filsafat hukum baru bangsa Indonesia yang digagas oleh Prof. Teguh Prasetyo, semua hukum yang berlaku di dalam suatu negara dan bangsa itu, termasuk hukum yang megnatur megnenai perlindungan data, merupakan perwujudan jiwa bangsa (Volksgeist) itu sendiri.

Sebagai suatu sistem, maka hukum yang manifestasinya terlihat dalam jiwa bangsa (Voksgeist) tersebut selalu lengkap dan self sufficient. Hukum itu sumber kebahagiaan, tidak mungkin hukum itu terlihat tidak lengkap, sehingga menjadi terlihat frustrasi, atau bahkan stres. Dengan perkataan lain, termasuk dalam semua hukum yang ada di dalam Volksgeist Indonesia itu, yaitu hukum yang mengatur tentang perlindungan data. Dalam perspektif Teori Keadilan Bermartabat seperti itu, tidak mungkin di dalam suatu sistem hukum tidak terdapat pengaturan seperti misalnya mengenai perlindungan data dan data pribadi.

Sebaliknya, selalu harus ada pengaturan hukum, termasuk pengaturan untuk melindungi data dan personal data di dalam sistem hukum Indonesia. Sehingga kalau terlontar pertanyaan seperti sudah dikemukakan di atas, yaitu: "apakah sudah ada hukum yang memberikan perlindungan terhadap data dan atau personal data di Indonesia"?, maka pertanyaan seperti itu di dalamnya terkandung frustrasi dari suatu sistem hukum. Hanya saja, wajar untuk dimaklumi, jika pertanyaan seperti itu terlucut dari mulut mereka yang awam tentang hukum.

Sekali lagi, untuk mendukung tesis di atas, perlu ditegaskan di sini, bahwa hukum yang mengatur tentang perlindungan data atau data protection di Indonesia juga dapat dijumpai eksistensinya di dalam sistem hukum Indonesia, seperti yang dikemukakan Prof. Supancana. Mengutip rumusan Pasal 28 G (1) UUD 45, Prof. Supancana berpendapat, bahwa:

Setiap orang berhak atas perlindungan diri pribadi, keluarga, kehormatan, matabat, dan harta benda yang di bawah kekuasaannya, serta berhak atas rasa aman dan perlindungan dari ancaman ketakutan untuk berbuat atau tidak berbuat sesuatu yang merupakan hak asasi.

Pandangan yang dilatarbelakangi oleh kepercayaan atau keyakinan diri yang tinggi dari jurist seperti Prof. Supancana itu sedikit bertolak belakang dengan pandangan awam mengenai hukum yang mengatur mengenai perlindungan data di Indonesia. Dimaksudkan dengan pandangan awam, yaitu khususnya dari kalangan mereka yang bukan jurists, seperti mereka yang mempelajari sosiologi hukum dan lain sebagainya. Pandangan awam itu justru sebaliknya mengatakan bahwa Indonesia benar-benar masih 
membutuhkan hadirnya suatu peraturan atau hukum yang khusus, peraturan hukum khusus tersebut mengatur tentang perlindungan data atau data protection.

Tidak ada yang salah dengan pandangan awam mengenai hukum tersebut. Orang awam hanya memegang prinsip yang sangat sederhana, bahwa kalau tidak ada undang-undang atau peraturan perundang-undangan yang secara khusus mengatur mengenai perlindungan data, sama seperti peraturan perundangan mengenai perlindungan data yang dimiliki di banyak negara di dunia saat ini, maka hal itu berarti di dalam sistem hukum itu belum ada hukum mengenai perlindungan data dimaksud. Pandangan orang awam seperti itu bertentangan sepenuhnya dengan cara jurist memandang hukum. Seorang jurist tidak pernah melontarkan kata-kata dari mulutnya bahwa hukum itu tidak lengkap, hukum itu tidak sempurna, hukum itu belum ada, atau hukum itu terlambat jika dibandingkan dengan masyarakatnya, atau dengan teknologi misalnya.

Sekalipun tidak ada yang salah bahwa orang memiliki pandangan awam sebagaimana dikemukakan di atas, pandangan itu terlalu sederhana dalam memahami hakikat hukum. Pandangan yang terlalu simplistis tentang hukum, dapat menghina hukum itu sendiri. Padahal negara Indonesia itu, menurut Konstitusinya adalah negara hukum. Suatu negara yang menyebut dirinya sebagai negara hukum berkewajiban untuk menjadikan hukum sebagai panglima, bukan hukum dijadikan pecundang.

Di samping sederhana, jikalau pandangan awam sebagaimana dikemukakan di atas dibiarkan, maka akan terjadi ketidakadilan yang sangat besar. Saya maksudkan dengan ketidakadilan yang sangat besar, yaitu orang dengan mudah saja mencari, menghimpun, mengolah dan menyimpan data pribadi dari seseorang secara salah atau keliru. Data pribadi yang didapatkan, diolah, disimpan secara keliru atau salah itu kemudian disebarluaskan ke media masa, baik itu konvensional maupun media elektronik, baik media yang tidak terhubung (off line) maupun yang dihubungkan dengan jaringan telekomunikasi (on line). Perbuatan untuk menyebarluaskan data pribadi yang tidak benar itu menjadi seolah-olah dibolehkan, karena alasan bahwa belum ada undang-undang atau peraturan perundang-undangan yang mengatur secara khusus menenai data protection di Indonesia.

Bagi orang awam, atau bagi mereka yang dalam buku teks pengantar ilmu hukum disebut dengan the men in the street, minus para polisi yang mengatur lalu-lintas di pinggir jalan, hukum itu sama atau identik dengan peraturan perundang-undangan, khususnya undang-undang. Bagi orang awam, jika tidak ada undang-undang atau jika tidak ada peraturan perundang-undangan maka tidak ada hukum, titik! Jika peraturan perundang-undangan itu sama dan sebangun dengan 
perlindungan hukum maka jika tidak ada peraturan perundang-undangan yang secara khusus mengatur mengenai perlindungan data, maka itu sama artinya dengan tidak ada perlindungan hukum atas data atau data pribadi.

Masih berkaitan dengan pandangan orang awam tentang hukum, ada mungkin saja lahir pandangan bahwa jika undang-undang atau peraturan perundang-undangan lainnya dapat dipersamakan dengan keadilan (justice), maka jika tidak ada undang-undang atau tidak ada peraturan perundangundangan yang mengatur secara khusus menenai data atau data pribadi, maka tidak ada keadilan yang berkaitan dengan data atau data pribadi tersebut.

Berikut di bawah ini, saya mengelaborasi lebih jauh kaidah dan prinsip bahwa Hukum Positif Indonesia pun, seperti telah ditunjukkan dengan keberadaan rumusan Pasal 28 G (1) UUD 45 di atas, telah menyediakan perlindungan hukum terhadap data, atau data pribadi (personal data). Hanya saja, seperti pula dikemukakan Prof. Supancana dalam Seminar Internasional di atas, persoalannya adalah meskipun di Indonesia ini ada hukum, atau lebih tepatnya sudah ada hukum yang mengatur mengenai data atau data pribadi, namun peraturan perundang-undangan yang mengatur mengenai data atau data peribadi tersebut masih belum terkodifikasi.

Dimaksudkan dengan belum terkodifikasi, yaitu terdapat berbagai rumusan ketentuan dan pengaturan mengenai perlindungan data, namun pengaturan itu masih tersebar di sana sini, tidak terhimpun dalam suatu buku undang-undang yang disusun secara khusus untuk itu. Dicontohkan oleh Prof. Supancana, seperti yang dikemukakan dalam Seminar Internasional tersebut di atas, beberapa undang-undang yang berkaitan dengan pengaturan perlindungan pribadi (privacy protection) di Indonesia.

Adapun berbagai undang-undang yang masih belum terkodifikasi dan yang berkaitan dengan perlindungan terhadap data pribadi dimaksud, yaitu: Undang-Undang No. 23 Tahun 2006 tentang Administrasi Kependudukan; Undang-Undang No. 29 Tahun 2004 tentang Praktik Kedokteran; UndangUndang No. 7 Tahun 2002 tentang Perubahan atas Undang-Undang No. 10 Tahun 1999 tentang Perbankan; Undang-Undang No. 15 Tahun 2002 yang telah diubah dengan UndangUndang No. 25 Tahun 2003 tentang Pencucian Uang; Undang-Undang No.36 Tahun 1999 tentang Telekomunikasi; Undang-Undang No. 26 Tahun 2007 tentang Ketentuan-Ketentuan Umum dan Prosedur Perpajakan; UndangUndang No. 9 Tahun 1992 tentang Imigrasi; Undang-Undang No. 11 Tahun 2008 tentang Informasi dan Transaksi Elektronik; Undang-Undang No. 14 Tahun 2008 tentang Kemerdekaan Informasi.

\section{Kaidah dan Asas Hukum tentang Perlindungan Data}

Terbukti, seperti telah dikemukakan di atas, bahwa dalam sistem hukum 
Indonesia juga sejatinya harus ada suatu himpunan kaidah dan asas hukum yang mengatur mengenai perlindungan data dan data pribadi. Hanya saja, seperti apakah kaidah dan asas yang mengatur mengenai perlindungan data dimaksud, hukum masih berdiam diri. Di Inggris, ungkapan yang digunakan untuk menggambarkan hukum yang masih berdiam diri dan belum berbicara mengenai kaidah dan asas-asas yang mendetail mengenai perlindungan data, sebagai contoh dalam artikel ini, yaitu: "the law is silent".

Di bawah ini, dengan mengandalkan rumusan ketentuan hukum sebagaimana dikemukakan Prof. Supancana dan sejalan dengan Teori Keadilan Bermartabat, berikut berbagai peraturan perundang-undangan yang berkenaan dengan perlindungan data, namun terlihat masih tersebar di sana sini dalam sistem hukum Pancasila, perlu dianalisis lebih mendalam untuk menemukan kaidah dan asas-asas hukum tentang perlindungan data. Hasil analisis membuktikan bahwa terdapat kaidah dan asas hukum yang dapat dipergunakan masyarakat dalam merespons peristiwa hukum seperti cerita Bainbridge dan pemberitaan tentang mega skandal Panamapepers.

Adapun kaidah dan asas hukum tentang perlindungan data dan perlindungan data pribadi yang semuanya penting untuk diketahui oleh mereka yang disebut sebagai pengguna data (data users). Di bawah ini dikemukakan suatu kaidah dan asas perlindungan data. Namun sebelumnya, perlu dikemukakan bahwa yang dimaksud dengan pengguna data atau data users adalah orang yang menguasai data. Di samping pengguna data, masih ada lagi pihak lain dalam hubungan hukum perlindungan data. Pihak dimaksud, yaitu subyek data atau yang umumnya dikenal dengan data subject. Pihak ini adalah seorang individu yang menjadi subyek dari data pribadi. Dia adalah manusia individual yang diidentikan dalam konsep data pribadi atau personal data.

Sedangkan yang dimaksud dengan data, yaitu informasi yang tersimpan dalam bentuk yang dapat diolah dengan peralatan yang beroperasi secara otomatis ketika merespons perintah yang diberikan untuk tujuan dibuatnya perintah tersebut. Sedangkan data pribadi atau personal data, yaitu data yang terdiri dari informasi yang berkaitan dengan manusia individual yang dapat dikenali dari informasi tersebut (atau dari informasi tersebut serta informasi lainnya dalam penguasaan dari pengguna data), termasuk di dalamnya semua pengungkapan pendapat tentang manusia individu yang bersangkutan namun dikecualikan, yaitu setiap tandatanda dari adanya suatu keinginan dari pengguna data mengenai individu yang bersangkutan.

Suatu kaidah atau asas hukum yang terdapat di dalam rumusan ketentuan Volksgeist, yang dikutip oleh Supancana di atas antara lain, yaitu bahwa informasi yang terdapat dalam data pribadi harus diperoleh, dan data pribadi harus diproses secara berimbang (fair) 
dan menurut hukum (lawfully). Kaidah atau asas hukum perlindungan data ini merupakan kaidah atau asas hukum yang paling fundamental dalam hukum telematika, atau dalam hal ini, yaitu hukum yang mengatur mengenai perlindungan data. Dimaksudkan dengan menurut hukum dalam kaidah atau asas perlindungan data bahwa informasi yang terdapat dalam data pribadi harus diperoleh, dan data pribadi harus diproses secara berimbang (fair) dan menurut hukum (lawfully), yaitu bahwa informasi dalam data pribadi harus diperoleh dan diproses dengan menuruti ketentuan hukum yang berlaku.

Contoh, yang a contrario untuk menerangkan apa yang dimaksudkan dengan "menurut hukum", adalah sebagai berikut. Seorang wartawan yang sedang melakukan kegiatan jurnalisme investigasi terhadap suatu perusahaan yang melakukan praktik monopoli (pricefixing) yang tidak sehat, berusaha memperoleh data dengan jalan melakukan suatu trik terhadap seorang pekerja pada perusahaan yang sedang diteliti agar si pekerja tersebut mau membuka data yang berkaitan dengan seorang manajer yang telah melakukan pertemuan dengan perusahaan kompetitor. Apa yang dilakukan oleh pihak pengguna data itu tidak dapat dikatakan sebagai tidak menurut hukum. Mengingat hal yang dilakukan oleh pihak wartawan tersebut bertujuan untuk memberikan perlindungan kepada kepentingan umum.

Sedangkan yang dimaksudkan dengan frasa "secara berimbang" atau fair dalam pengumpulan dan pemrosesan, serta pengolahan dan penggunaan data, dapat dijelaskan dengan memperhatikan ilustrasi sebagai berikut. Lembaga-lembaga pemberi pinjaman kredit pasti memegang informasi terperinci mengenai pihak yang menerima pinjaman. Lembagalembaga pemberi pinjaman non-bank itu biasanya menghimpun informasi pribadi dimaksud untuk diberikan kepada pihak ketiga yang membutuhkannya, misalnya Bank yang memberikan pinjaman kepada lembaga pemberi pinjaman kredit.

Apabila lembaga yang diberikan kredit oleh pihak Bank itu memiliki trak rekord yang buruk, misalnya teridentifikasi memiliki apa yang disebut sebagai bad credit risk, maka boleh jadi pihak subyek data yang sudah melunasi pinjamannya kepada lembaga non-bank yang memberikan pinjaman dimaksud akan ikut tercemar namanya. Akibatnya, apabila pihak yang tadinya menerima pinjaman dari lembaga nonbank ingin meminjam uang di Bank, maka kemungkinan Bank menolak memberi pinjaman. Apabila data demikian itu masih tersimpan di lembaga pemberi pinjaman non-bank maka pihak lembaga pemberi pinjaman non-bank dapan dikategorikan sebagai pihak pengguna data yang menyalahi kaidah atau asas perlindungan ata yang pertama sebagaimana dikemukakan di atas.

Dalam kasus Panamapapers, khususnya yang menimpa para petinggi negeri seperti Rini dan Luhut di atas, 
ada kemungkinan benar bahwa sebelumnya Menteri Rini dan Luhut pernah menanamkan modal mereka di negara pulau sebagaimana dikemukakan di atas. Hanya saja, saat ini mereka sudah tidak memiliki keterkaitan lagi dengan binis yang diungkap dalam Panamapapers. Sementara data yang masih disimpan dalam Panamapapers terlanjur bocor ke publik. Pihak yang bertanggung jawab menghimpun dan menggunakan data kedua menteri di atas dengan demikian telah menyalahi kaidah dan asas perlindungan data yang pertama sebagaimana dikemukakan di atas. Sehingga secara hukum, seharusnya data menteri Rini, Luhut an Azis yang ada di dalam Panamapapers yang sempat dianggap sebagai skandal itu seharusnya tidak lagi memiliki makna apa pun.

Sekedar suatu perbandingan tentang contoh di negara lain mengenai kaidah atau asas perlindungan data bahwa informasi yang terdapat dalam data pribadi harus diperoleh, dan data pribadi harus diproses secara berimbang (fair) dan menurut hukum (lawfully), dapat dikemukakan di sini suatu kasus di Inggris, yaitu Innovations (Mail Order) Ltd v. Data Protection Registrar yang diputus oleh Data Protection Tribunal. Dalam kasus tersebut, suatu perusahaan bernama Innovations menjalankan usaha dalam bidang Mail Order. Bentuk usaha ini disebut Mail Order karena perusahaan Innovations menyelenggarakan penjualan dan pembelian barang secara masal melalui surat. Barang-barang yang diperjualbelikan diiklankan melalui katalog, koran dan televisi. Perusahaan bernama Innovations itu juga menjalankan bisnis yang maju dan paling menguntungkan lainnya, yaitu menjual suatu daftar yang berisi informasi menenai pelanggannya kepada berbagai perusahaan retailer, dan penyedia jasa. Bisnis yang dijalankan oleh Innovations itu di Inggris disebut dengan list trading.

Menjadi sengketa ke Pengadilan, karena pihak pelanggan dari perusahaan Innovations tersebut ketika memesan dan membeli barang melalui jasa Inovations tersebut tidak pernah diberitahu bahwa Innovations menyelenggarakan apa yang disebut di atas sebagai list trading pada saat para pelanggan dari Inovations itu memesan barang yang akan mereka beli melalui Inovations. Pemberitahuan itu baru dilakukan oleh Inovations ketika para pelanggan itu menerima suatu tanda terima dari pesanan mereka bahwa para pelanggan itu sudah diinformasikan mengenai hal itu melalui suatu surat pemberitahuan yang dicantumkan di lembaran sebaliknya dari nota tanda terima tersebut. Pemberitahuan yang tertera di balik nota tanda terima itu pada intinya, yaitu bagi para pelanggan dapat menghapus nama atau informasi mengenai diri mereka dari daftar pelanggan yang akan diperdagangkan oleh perusahaan yang bernama Innovations tersebut. Namun penghapusan nama-nama dan segala informasi mengenai pelanggan dari Inovations dimaksud baru dilakukan apabila pelanggan tersebut mengajukan permohonan secara tertulis dan di dalam 
permohonan itu tercantum nama dan alamat dari para pelanggan Inovations yang tidak setuju namanya dicantumkan dalam daftar nama-nama pelanggan yang akan diperdagangkan oleh Innovations.

Menurut Pengadilan, atau yang disebut di Inggris dengan the Registrar, Innovations telah melakukan perbuatan melawan hukum atau the breach of the principle that the information to be contained in personal data shall be obtained, and personal data shall be processed, fairly and lawfully. Dikatakan merupakan perbuatan melawan hukum karena data yang dihimpun oleh perusahaan Innovations tersebut tidak diperoleh secara adil dan berimbang (fairly). Tidak adil, menurut Pengadilan atau Registrar, sebab seharusnya persetujuan dari pihak pelanggannya Innovations itu harus diberikan oleh Innovations pada saat pengumpulan data itu dilakukan, bukan seperti yang dilakukan, yaitu pemberitahuan disampaikan belakangan.

Putusan Registrar itu dikuatkan hakim Tinggi atau The Tribunal. Menurut The Tribunal, mengingat maksud dari pengumpulan data pihak pelanggan itu adalah agar data itu nantinya akan diperdagangkan oleh pihak Innovations, maka menurut pihak Tribunal, adalah fair, mengingat tujuan dari pihak Innovations itu tidak merupakan tujuan yang nyata dapat dilihat dan diketahui. Karena tujuan dari pihak Inovations itu belum tentu dapat diketahui pihak pelanggannya, maka menurut hukum pihak Innovations harus memberitahukan kepada para pelanggannya di awal bahwa namanama mereka itu akan dicantumkan dalam List untuk kemudian diberikan kepada pihak ketiga.

Klarifikasi teoretis atas maksud dari frasa secara berimbang dan adil (fair) yang terambil dari studi perbandingan dengan sistem hukum Inggris melalui Putusan Innovations (Mail Order) Ltd $v$. Data Protection Registrar di atas menarik untuk diaplikasikan dalam Panamapapers. Para petinggi negeri yang namanya diedarkan kepada pihak ketiga, dalam hal ini melalui pembocoran data melalui Panamapapers itu dilakukan secara melawan hukum. Dimaksud, yaitu melawan asas atau kaidah perlindungan data sebagaimana dikemukakan di atas. Bahkan, apa yang ada di Inggris dalam contoh di atas, sejatinya ada pula, meminjam Teori Keadilan Bermartabat, dalam Volksgeist Indonesia yang memanifestasikan diri secara konkret melalui Undang-Undang No. 11 Tahun 2008 tentang ITE.

Dirumuskan dalam Pasal 26 Ayat (1) UU ITE bahwa: "Kecuali ditentukan lain oleh Peraturan Perundang-Undangan, penggunaan setiap informasi melalui media elektronik yang menyangkut data pribadi seseorang harus dilakukan atas persetujuan Orang yang bersangkutan". Dijelaskan dalam rumusan Penjelasan atas Pasal 26 Ayat (1) UU ITE tersebut, bahwa:

Dalam pemanfaatan Tekonologi informasi, perlindungan data pribadi merupakan salah satu bagian dari hak pribadi (privacy rights). Hak pribadi mengandung pengertian sebagai berikut: a. Hak pribadi merupakan hak untuk menikmati kehidupan pribadi 
dan bebas dari segala macam gangguan; b. Hak pribadi merupakan hak untuk dapat berkomunikasi dengan Orang lain tanpa tindakan memata-matai; c. Hak pribadi merupakan hak untuk mengawasi akses informasi tentang kehidupan pribadi dan data seseorang.

Berbeda dengan penyelesaian melalui the Registrar dan the Tribunal apabila pelanggaran terhadap kaidah dan asas perlindungan data terjadi di Inggris, maka penyelesaian atas pelanggaran terhadap asas dan kaidah yang sama di Indonesia diatur dalam Pasal 26 Ayat (2) UU ITE. Dirumuskan di sana, bahwa: "Setiap orang yang dilanggar haknya sebagaimana dimaksud pada ayat (1) dapat mengajukan gugatan atas kerugian yang ditimbulkan berdasarkan undangundang ini”. Dimaksudkan dengan frasa "undang-undang ini" dalam Pasal 26 Ayat (2) tersebut, yaitu UU ITE. Dalam kasus Panamapapers, nyata sekali ada keluhan dari pihak-pihak petinggi negara sebagiamana dikemukakan di atas bahwa mereka telah dirugikan oleh Panamapapers. Namun, apakah mereka akan menggunakan sarana penyelesaian hukum yang telah disediakan dalam Sistem Hukum Pancasila, yaitu Volkgeist Indonesia yang tertulis secara konkret dalam Pasal 26 Ayat (2) UU ITE, waktulah yang nantinya akan membuktikan.

\section{PENUTUP}

Demikianlah gambaran singkat tentang perlindungan data atau data protection di dalam sistem hukum Indonesia. Memperhatikan gambaran dan analisis sebagaimana dikemukakan di atas dapat disimpulkan bahwa meskipun di Indonesia belum ada Undang-Undang yang khusus mengenai Perlindungan Data yang sama seperti sudah digunakan di banyak negara di dunia, namun pada prinsipnya, dalam perspektif Teori Keadilan Bermartabat, Volksgeist Indonesia, yaitu Pancasila, yang mewujudnyatakan diri secara konkret dalam UU ITE telah mengandung asas dan kaidah hukum perlindungan data dan personal data.

Sekarang terpulang kepada pihakpihak yang dirugikan karena adanya pelanggaran terhadap asas dan kaidah hukum yang mengatur perlindungan data atau data pribadi, apakah mereka mau atau tidak menggunakan sarana yang sudah disediakan untuk memulihkan kerugian yang menimpa diri mereka ke keadaan semula, misalnya memulihkan nama baik mereka yang mungkin telah tercemar oleh skandal Panamapapers. Hukum Indonesia memungkinkan hal itu. Seperti telah dikemukakan di atas, inisiatif para petinggi negara yang dirugikan itu masih ditunggu. Atau mungkin waktu untuk menggunakan apa yang telah tersedia dalam hukum itu masih belum pas apabila dilakukan sekarang.

\section{DAFTAR BACAAN}

\section{Buku}

Bainbridge, David I, Introduction to Computer Law (Financial Times Pitman Publishing, 1996). 
Prasetyo, Teguh, Keadilan Bermartabat Perspektif Teori Hukum (Nusa Media, 2015).

\section{Lain-lain}

Supancana, I Made, dalam Kumpulan Bahan Seminar Internasional Personal Data Protection, Faculty of Law, University of 17 August 1945 Surabaya, 31 Maret 2016.

Majalah Times, 8 Mei 1990. 